\title{
Against All Odds
}

by Jillian Rothwell. Northland: David Ling Publishing Ltd, 2020.

RRP: \$34.99 ISBN: 978-1-927305-66-9

Reviewed by Margot Schwass

More than eighty years on from the Holocaust, what Elie Wiesel called the 'duty to bear witness for the dead and for the living' continues to find literary expression. This year alone, a forgotten novel written at breakneck speed by an exiled German Jew in the aftermath of Kristallnacht Ulrich Alexander Boschwitz's, The Passenger, described as part John Buchan, part Franz Kafka - was unearthed and published in translation by Pushkin Press in London, while previously-unheard testimonies of Nazi 'death march' survivors have been transcribed to form the centrepiece of an important new exhibition in the same city.

But as the direct survivors of Nazi persecution dwindle in number, it is chiefly their children and grandchildren who continue the task of bearing witness, in fiction, biography, history and memoir. Exactly what they are bearing witness to is somewhat different from the previous generation. Survivors of the camps, said Primo Levi, wrote out of both 'a moral and civil obligation' and 'a primary, liberating need', compelled to record a history that could not be imagined but could all too readily be denied. For their descendants, writing the stories of those who survived and those who perished is both an act of remembrance and a means of confronting and interpreting their own histories. They speak of living in the aftermath of the unimaginable, surrounded by gaps and erasures and sometimes by lies, bound to a past that has been obliterated yet remains ever-present. The children of refugees and exiles, they have been burdened with their parents' sadness - sometimes to the point of resentment - but remain excluded from it too, another confirmation of a seemingly indelible 'foreignness'. Ann Beaglehole's Facing the Past - based on interviews with the children of the European refugees who arrived in New Zealand from Nazi Europe in the 1930s and 40s - remains a compelling testament to this experience.

Much of the writing of second and third generation Holocaust writers is inflected with these discomforts. They write to find answers and fill voids; they write to honour the dead and give them voice. But all the while, they are also writing their own stories, inserting themselves freely into their narrative as they reckon with the absences, silences and sometimes lies that have framed their lives. Often a family memento or keepsake becomes a talisman as the author goes in search of his or her past. For Edmund de Waal in The Hare With Amber Eyes, it is the collection of tiny Japanese carvings, netsuke, that he inherits from his great-uncle; for Bart van Es in The Cut Out Girl, it is a young girl's sentimental scrapbook. For Philippe Sands, author of East West Street, an invitation to a conference in Lemberg becomes a portal into his family's past, while Diana Witchel's untangling of her lost father's story in Driving to Treblinka begins with the medical records of his death in a Canadian hospital.

For New Zealander Jillian Rothwell, the starting point is some battered leather suitcases containing a cache of family letters and documents, retrieved from the attic of her parents' home in Palmerston North. Among the contents is her Jewish grandfather Abraham Bieder's wartime diary, a record of anguish and privation written largely in Brussels where Abraham and his wife Bertha spent the war in hiding. The diary was translated decades later by their son Ludwig - Jillian's father - who had escaped to New Zealand as a refugee in October 1939. Against All Odds traces a series of family migrations, both forced and chosen, that range from the eastern edges of the Hapsburg Empire, to Vienna on the eve of the Anschluss, to Foxton in 
the Manawatū, and back to the ruins of postwar Europe. The most recent journey is Rothwell's, travelling to the eastern edges of the old Austro-Hungarian Empire in search of her family's origins.

But it is her father's journey that lies at the heart of the book. In 1938, Ludwig Bieder is a young Viennese doctor whose professional and personal ambitions are rapidly extinguished by anti-Semitic sentiment and legislation. On the very day that Hitler's motorcade rolls into the city, Ludwig prepares to flee, leaving behind his parents, a lover, and the prosperous life of the Viennese bourgeoisie. By sheer good fortune, he secures an entry visa to New Zealand, arriving in Wellington, 'a small unworldly town on the other side of the world, filled with predominantly British people still very loyal to the mother country.' Ludwig finds work as a hospital orderly. Washing sputum cups and mopping floors soon stiffens his determination to resume his career, even it means repeating much of his medical training. It also means withstanding the scepticism of a profession that - with notable individual exceptions - is unapologetically resistant to outsiders ('I will never let a foreigner look through my cystoscope,' one local surgeon remarked cryptically).

Charming, sociable and apparently able to keep at bay his mounting fears for his family (he would not hear from them for six years), Ludwig throws himself enthusiastically into his second medical career and his own reinvention, first in Dunedin and then in Wellington. He gives himself a jaunty British name, Lewis, and marries the daughter of a well-established Wellington family (Lois Little, whose respectable forebears had worshipped at the city's Anglican cathedral alongside the Beauchamps in the early years of the century). He embraces life as a rural GP, first in Tuatapere and then in Foxton, where Lewis and Lois spend the remainder of the war - popular members of the community but enemy aliens nonetheless. It is in Foxton that their first daughter is born, followed by four more. Jillian is born after the war in Palmerston North, where Lewis subsequently practises as a gastroenterologist and becomes medical director of Glaxo New Zealand.

While Ludwig was becoming Lewis in New Zealand, his parents and other family members remained in Europe. Some, astonishingly, survived the war. Others were erased by the familiar horrors; shot, deported, starved, gassed or simply vanished. Lewis's parents Abraham and Bertha were among the luckier ones. Considering themselves more Austrian than Jewish, they clung to their elegant apartment near the Ringstrasse, their astrakhan coats, and seats at the opera until it was very nearly too late. Still in a state of disbelief, they were persuaded to make a dangerous escape from occupied Austria and fled to Belgium. They spent most of the war there, sick, starving and at constant risk of discovery. It was in Brussels that they were finally reunited with their son, when Lewis and Lois travelled to Europe in 1947 to 'retrieve' them. Abraham and Bertha later moved to New Zealand where they remained until their deaths. But unlike their son, they never truly settled here, Rothwell writes; they found the magnitude of their loss simply too great to confront and never fully accepted that they 'had left Europe for good'.

Rothwell is a committed and diligent chronicler of her family's European origins, reaching back into the 'dark and violent' shtetl life of Galicia and Bukovina, as well as the more obvious charms of fin-de-siècle Vienna. She writes of her father's life in New Zealand with affection and obvious admiration. He emerges as a man ferociously determined to both survive and succeed in his new home, and seems to have managed to live more comfortably in the 
characteristically stretched skin of the refugee than many. Ludwig's is the central story in the book, and Rothwell does it justice.

Yet, as Jonathan Freedland has written recently, readers are drawn to post-Holocaust literature for both the story in the book and the story of the book - the story of the author's reckoning with their own experience. In this respect, Rothwell seems to be holding something back, tending to remain at a distance from the intensely personal story she is telling, reporting it rather than situating herself within it, sometimes flattening its specific contours with passages of generic, oddly colourless prose. Likewise, the talismanic leather suitcases remain a treasure trove whose riches Rothwell does not fully exploit. Apart from in one chapter, neither Abraham's diary nor the letters from father to son - written when neither knew if the other was still alive - are as powerfully present as they could be.

One of the biggest challenges for anyone who sets out to write about the Holocaust remains one of scale: what language and register can possibly match the inhumanity that is their subject or adequately render its horrors? Ultimately, perhaps what Holocaust literature can do best is to fill absence with presence, to counter a grotesque attempt at mass erasure with an emphatic shout of denial - 'we are still here'. In documenting her family's survival story, Jillian Rothwell has added to that defiant assertion. 